\title{
Nociceptin Receptor Impairs Recognition Memory via Interaction with NMDA Receptor-Dependent Mitogen- Activated Protein Kinase/Extracellular Signal-Regulated Kinase Signaling in the Hippocampus
}

\author{
Celia Goeldner, ${ }^{1}$ David Reiss, ${ }^{1}$ Jürgen Wichmann, ${ }^{3}$ Hamid Meziane, ${ }^{2}$ Brigitte L. Kieffer, ${ }^{1}$ and \\ Abdel-Mouttalib Ouagazzal ${ }^{1}$ \\ ${ }^{1}$ Institut de Génétique et de Biologie Moléculaire et Cellulaire and ${ }^{2}$ Institut Clinique de La Souris, 67404 Illkirch, France, and ${ }^{3}$ Pharmaceuticals Division, \\ Discovery Chemistry, F. Hoffmann-La Roche, CH-4070 Basel, Switzerland
}

\begin{abstract}
Strong evidence suggests a role for nociceptin/orphanin FQ (N/OFQ) neuropeptide and its receptor (NOP) in cognition. However, the signaling mechanisms underlying N/OFQ modulation of memory are less understood. Here, we show that intracerebroventricular or intrahippocampal infusions of N/OFQ impair long-term memory formation in the mouse object recognition task. The synthetic NOP receptor agonist, (1S,3aS)-8-(2,3,3a,4,5,6-hexahydro-1H-phenalen-1-yl)-1-phenyl-1,3,8-triaza-spiro[4.5]decan-4-one (Ro64-6198), administered systemically, also produced amnesic effects that were blocked by coinfusion of the NOP receptor antagonist, [Nphe1,Arg14,Lys15]nociceptin-NH2 (UFP-101), into the dorsal hippocampus. In contrast, Ro64-6198 had no effect on short-term memory or recall performances. Immunoblotting analysis revealed a strong suppressive action of Ro64-6198 on learning-induced upregulation of hippocampal extracellular signal-regulated kinase (ERK) phosphorylation, which is crucial for long-term information storage. Accordingly, pharmacological inhibition of ERK activation after systemic injection of SL327 [ $\alpha$-[amino[(4-aminophenyl)thio]methylene]-2-(trifluoromethyl)benzene acetonitrile], a selective inhibitor of the upstream kinase MEK (mitogen-activated protein kinase kinase), abolished long-term recognition memory formation. The noncompetitive NMDA receptor antagonist $(+)$-5-methyl10,11-dihydro-5H-dibenzo [a,d]cyclohepten-5,10-imine maleate (MK-801), given systemically, also suppressed ERK activation and disrupted recognition memory. In contrast, no effect of MK-801 was observed on recall, as for Ro64-6198. When administered concurrently at subthreshold doses, Ro64-6198 and MK-801 synergistically suppressed hippocampal ERK activation and impaired long-term memory formation. Under resting conditions, neither Ro64-6198 nor MK-801 affected spontaneous ERK activity in the hippocampus at the amnesic doses whereas at higher doses, only MK-801 had a suppressive effect. We conclude that N/OFQ-NOP receptor system negatively regulates long-term recognition memory formation through hippocampal ERK signaling mechanisms. This modulation may in part take place by inhibiting glutamatergic function at the NMDA receptor.
\end{abstract}

Key words: opioid; NOP receptor; NMDA receptor; hippocampus; recognition memory; ERK; mice

\section{Introduction}

Nociceptin/orphanin FQ (N/OFQ) is an opioid-like neuropeptide that selectively binds to the NOP receptor (formerly orphan opioid receptor-like-1) (Meunier et al., 1995; Reinscheid et al., 1995). Since its discovery a decade ago, this neuropeptidereceptor system has been implicated in a host of biological functions (Chiou et al., 2007). One of the most established findings is

\footnotetext{
Received Aug. 15, 2007; revised Jan. 15, 2008; accepted Jan. 15, 2008.

This work was supported by the Centre National de la Recherche Scientifique, the Institut National de la Santé et de la Recherche Médicale, the Université Louis Pasteur de Strasbourg, and National Institute of Drug Abuse Grant DA05010. C. Goeldner was supported by a grant from the French Government (Ministère de la Recherche et de l'Enseignement Supérieur).

Correspondence should be addressed to Dr. Abdel-Mouttalib Ouagazzal, Institut de Génétique et de Biologie Moléculaire et Cellulaire, 1 Rue Laurent Fries, BP 10142, 67404 Illkirch, France. E-mail address: Abdel-Mouttalib.OUAGAZZAL@igbmc.u-strasbg.fr.

DOI:10.1523/JNEUROSCI.3711-07.2008

Copyright $\odot 2008$ Society for Neuroscience $\quad 0270-6474 / 08 / 282190-09 \$ 15.00 / 0$
}

the importance of this system in cognition. N/OFQ and its receptor are densely expressed in brain regions associated with learning and memory processes, such as the hippocampus, the amygdala, and the cerebral cortex (Darland and Grandy, 1998; Neal et al., 1999a,b). Furthermore, NOP receptor activation with N/OFQ or synthetic agonists impairs memory performances in a variety of cognitive tasks in rodents (Sandin et al., 1997; Hiramatsu and Inoue, 1999; Redrobe et al., 2000; Higgins et al., 2002; Mamiya et al., 2003; Liu et al., 2007; Roozendaal et al., 2007), whereas the deletion of NOP receptor or preproN/OFQ gene produces the opposite effects (Manabe et al., 1998; Higgins et al., 2002; Mamiya et al., 2003). Consistent with these findings, electrophysiological studies showed that N/OFQ potently inhibits synaptic transmission and synaptic plasticity in the hippocampus and the amygdala (Yu et al., 1997; Meis and Pape, 1998; Yu and Xie, 1998; Wei and Xie, 1999; Bongsebandhu-phubhakdi and Manabe, 2007). 
Despite these advances, the signaling mechanisms underlying NOP receptor modulation of memory remain largely unknown. Memory formation depends on activation of intracellular signaling pathways and gene expression required for synaptic plasticity and long-term storage of information. Recently, there has been considerable interest in the role of mitogen-activated protein kinases (MAPKs) in cognition as they are an essential component of the transduction mechanisms leading to transcriptional activity in neurons (Sweatt, 2004; Davis and Laroche, 2006; Giovannini, 2006). The extracellular signal-regulated kinase (ERK) MAPK plays a pivotal role in synaptic plasticity and several forms of hippocampusdependent memories (Sweatt, 2004; Davis and Laroche, 2006; Giovannini, 2006). After activation, ERK can translocate to the nucleus and target transcription factors, such as CREB (cAMP response element-binding protein) and Elk (Sweatt, 2001; Davis et al., 2006; Giovannini, 2006), which, in turn, trigger memory-associated gene expression. Many neurotransmitter receptors which facilitate memory formation and promote synaptic plasticity, including the glutamatergic NMDA receptor, positively regulate ERK activity in hippocampal neurons (Poser and Storm, 2001; Sweatt, 2004). NOP receptor was also shown to activate this signaling pathway in transfected cell lines (Fukuda et al., 1997; New and Wong, 2002); however, no information is available with regard to its action in brain neurons. Based on behavioral and electrophysiological studies, we hypothesized that NOP receptor would rather inhibit ERK activity in hippocampal neurons during learning. In this study, we provide evidence for this hypothesis using a mouse object recognition task. We show that NOP receptor activation impairs long-term recognition memory formation by inhibiting NMDA receptor-mediated ERK activation in the hippocampus. However, NOP receptor does not seem to modulate hippocampal ERK activity under resting conditions, unlike the NMDA receptor which constitutively activates this signaling pathway.

\section{Materials and Methods}

Animals. Eight-week-old C57BL/6N male mice were purchased from Charles River Laboratory (St-Germain-sur-l'arbresle, France), and housed four per cage in individually ventilated cages (M.I.C.E. cages; Charles River Laboratory) with water and food ad libitum. Mice were maintained on a $12 \mathrm{~h}$ light/dark cycle (light on at 7:00 A.M., off at 7:00 P.M.) and were allowed 4-6 weeks of acclimatization before surgery or testing. Behavioral testing was performed during the light cycle between 9:00 A.M. and 5:00 P.M. All experimental procedures were performed on naive mice and according to the European Union guidelines.

Surgery and infusion procedure. Mice were anesthetized with a mixture of ketamine $(100 \mathrm{mg} / \mathrm{kg})$ and xylazine $(10 \mathrm{mg} / \mathrm{kg})$ and placed in a stereotaxic frame (Unimécanique, Epinay-sur-Seine, France). The skull was exposed and the incisor bar adjusted such that bregma and $\lambda$ were at the same height. An 8-mm-long stainless-steel guide cannula ( $0.4 \mathrm{~mm}$ external diameter; Cortat, Courrendlin, Switzerland), was positioned $1 \mathrm{~mm}$ over the lateral ventricule [coordinates: anteroposterior (AP), $-0.16 \mathrm{~mm}$; lateral (L), $+1 \mathrm{~mm}$ from the bregma; dorsoventral (DV), $-2 \mathrm{~mm}$ from the skull surface] according to the atlas of Paxinos and Watson (2001). For hippocampal implantation, 8 $\mathrm{mm}$ long stainless-steel guide cannulas $(0.4 \mathrm{~mm}$ external diameter $)$ were positioned bilaterally $1 \mathrm{~mm}$ over the dorsal hippocampus (coordinates: AP, $-2 \mathrm{~mm} ; \mathrm{L}, \pm 1.6 \mathrm{~mm}$ from the bregma; DV, $-1.2 \mathrm{~mm}$ from the skull surface). To control for anatomical specificity, a group of mice was implanted bilaterally in an area adjacent to the hippocampus. The injection sites were positioned into the somatosensory cortex above the hippocampus (coordinates: AP, $-1.8 \mathrm{~mm} ; \mathrm{L}, \pm 3.0 \mathrm{~mm}$ from the bregma; DV, $-0.3 \mathrm{~mm}$ from the skull surface). The cannulas were fixed to the skull with anchoring screws and dental cement. Wire stylets were inserted into the cannulas to prevent occlusion. After surgery, mice were housed two per cage and allowed to recover at least 1 week before behavioral testing. During this period, stylets were replaced to keep the cannulas patent and custom the animals to handling. Intracerebral infusions were performed with stainless-steel injector needles $(0.28 \mathrm{~mm}$ external diameter $)$ that protruded the cannula by $1 \mathrm{~mm}$, into the lateral ventricule, the dorsal hippocampus, or the cortex. Intracerebroventricular injections were made in a volume of $2 \mu \mathrm{l}$ at rate of $1 \mu \mathrm{l} / \mathrm{min}$ via Hamilton syringe mounted on a microdrive pump (Harvard Apparatus, Les Ulis, France). Intrahippocampal infusions were made in a volume of $0.25 \mu \mathrm{l} /$ side at rate of 0.125 $\mu \mathrm{l} / \mathrm{min}$. This injection volume was selected based on previous studies (Daumas et al., 2005; Fischer et al., 2007).

Object recognition task and experimental design. Testing was performed in dimly lit (50 lux) open-field arenas $\left(44 \times 44 \times 17 \mathrm{~cm}^{3}\right.$; Panlab, Barcelona, Spain) fitted with infrared beam frames, which provide automated measures of locomotor activity (Actitrack, Barcelona, Spain). The general procedure consisted of three different phases carried over 3 consecutive days (Dodart et al., 1997). On the first day, mice were habituated to the experimental conditions and open-field arena for $30 \mathrm{~min}$. The following day, they were submitted to a $10 \mathrm{~min}$ familiarization trial in the presence of an object A (dice or marble) placed in the northeast or northwest corner of the open-field arena. The presentation of the objects (dice or marble) as well as their position (northeast or northwest) was counterbalanced between mice for each treatment. The time spent exploring the object $\left(T_{1} \mathrm{~A}\right)$, defined as head oriented within $1-2 \mathrm{~cm}$ and toward the object, was hand-scored with a stopwatch. Minimum exploration time was set to $3 \mathrm{~s}$, and mice that did not reach this criterion were excluded from the study. On the third day, mice were submitted to a 10 min choice trial in the presence of the familiar object (A) placed in the same corner, and a novel object (B) placed in the opposite corner. The time spent exploring the two objects ( $T_{2} \mathrm{~A}$ and $T_{2} \mathrm{~B}$, respectively) was manually scored for $10 \mathrm{~min}$. After each run, arenas and objects were cleaned. The experimenter scoring mouse behavior was blind to drug treatment. The discrimination index $(\mathrm{DI})$ was defined as $\left(T_{2} \mathrm{~B} /\left(T_{2} \mathrm{~A}+T_{2} \mathrm{~B}\right) \times 100\right)$. A DI of $50 \%$ corresponds to chance level and a significantly higher DI reflects good recognition memory.

Drugs and injections. The N/OFQ peptide and the peptidic NOP receptor antagonist [Nphe1,Arg14,Lys15]nociceptin-NH2 (UFP101) were synthesized in house (Institut de Génétique et de Biologie Moléculaire et Cellulaire peptide synthesis platform) and were dissolved in artificial CSF containing (in $\mathrm{mm}$ ) $126.6 \mathrm{NaCl}, 27.4 \mathrm{NaHCO}_{3}$, $2.4 \mathrm{KCl}, 0.5 \mathrm{KH}_{2} \mathrm{PO}_{4}, 0.89 \mathrm{CaCl}_{2}, 0.8 \mathrm{MgCl}_{2}, 0.48 \mathrm{Na}_{2} \mathrm{HPO}_{4}$, and 7.1 glucose, $\mathrm{pH}$ 7.4. Intracerebroventricular and intrahippocampal injections took place 5 and 2 min before the familiarization trial, respectively. Control groups received corresponding volume of CSF. (1S,3aS)-8-(2,3,3a,4,5,6-hexahydro- $1 H$-phenalen-1-yl)-1-phenyl1,3,8-triaza-spiro[4.5]decan-4-one (Ro64-6198) (a generous gift from Hoffmann-La Roche, Basel, Switzerland), an NOP receptor agonist, was dissolved in saline $(0.9 \% \mathrm{NaCl})$ containing $0.3 \%$ Tween 20 and injected intraperitoneally at a volume of $10 \mathrm{ml} / \mathrm{kg}$, with $30 \mathrm{~min}$ pretreatment time. (+)-5-Methyl-10,11-dihydro-5H-dibenzo [a,d]cyclohepten-5,10-imine maleate (MK-801; Sigma, St Quentin Fallavier, France), a noncompetitive NMDA receptor antagonist, was dissolved in saline $(0.9 \% \mathrm{NaCl})$ and injected subcutaneously at a volume of $10 \mathrm{ml} / \mathrm{kg}$, with $30 \mathrm{~min}$ pretreatment time. $\alpha$-[Amino[(4aminophenyl)thio]methylene]-2-(trifluoromethyl)benzene acetonitrile (SL327) (Sigma) MAPK kinase (MEK)/ERK inhibitor, was dissolved in DMSO and injected intraperitoneally at a volume of $2 \mathrm{ml} / \mathrm{kg}$, with $1 \mathrm{~h}$ pretreatment time, based on previously described procedures (Atkins et al., 1998; Selcher et al., 1999).

Hippocampal MAPK analysis. The phosphorylated state of ERK and c-Jun N-terminal protein kinase (JNK) in the hippocampus was detected by Western blotting. For the time course study, mice were habituated $30 \mathrm{~min}$ to the open field arena. The following day, the mice were killed, either immediately after ( 0 min condition) or $30 \mathrm{~min}$ after a 10 min exposure to an object (familiarization trial). Mice presented 
to an empty open field arena served as controls. For drug studies, mice were killed $30 \mathrm{~min}$ after the familiarization trial, and vehicle-treated mice served as controls. Immediately after decapitation, the hippocampus was rapidly dissected and kept at $-80^{\circ} \mathrm{C}$. Frozen hippocampi were then homogenized and sonicated in $2 \%$ SDS buffer containing (in mM) 50 Tris, pH 6.8, 1 EDTA, 1 sodium fluoride, and 1 sodium orthovanadate, as well as a complete protease inhibitor mixture (Roche Applied Science, Indianapolis, IN). Homogenates were boiled at $96^{\circ}$ for $4 \mathrm{~min}$, and total protein content was determined by Bradford assay. Twenty micrograms of protein were loaded on a SDS-10\% bisacrylamide gel and separated by constant voltage of 100 $\mathrm{V}$ for $1 \mathrm{~h}$, then transferred to polyvinylidene difluoride membranes at a constant voltage of $100 \mathrm{~V}$ for $1 \mathrm{~h}$ in cold transfer buffer (Trisborate). Membranes were blocked in $5 \%$ nonfat dry milk in a Trisbuffered saline (TBS) solution containing $0.1 \% \mathrm{v} / \mathrm{v}$ Tween 20 , for $1 \mathrm{~h}$. Activated MAPK were recognized with primary anti-phospho-MAPK antibodies [anti-phospho-p44/42 MAPK/ERK (Thr202/Tyr204) monoclonal antibody, 1:4000, or anti-phospho-SAPK/JNK (Thr183/ Tyr185) rabbit mAb, 1:1000; Cell Signaling Technology, Beverly, MA] diluted in blocking solution and incubated overnight at $4^{\circ} \mathrm{C}$. Membranes were washed three times for $5 \mathrm{~min}$ in TBS solution and incubated for $1 \mathrm{~h}$ at room temperature in horseradish peroxidase conjugated anti-mouse or anti-rabbit IgG secondary antibodies (1:20,000; GE Healthcare, Saclay, France). The signal was revealed using enhanced chemiluminescent reagents (ECL+; GE Healthcare) and directly quantified using a CDD camera (Chemigenius ${ }^{2}$ apparatus; SynGene, Dorset, UK) allowing image capture (GeneSnap software; SynGene) and direct blot analysis (GeneTools software; SynGene). To analyze the total MAPK content of samples, membranes were then stripped of antibodies for $20 \mathrm{~min}$ (Re-blot plus solution; Millipore, St. Quentin, France), rinsed, and blocked at room temperature for $1 \mathrm{~h}$. Blots were reincubated with total MAPK primary antibody (antip44/42 MAPK/ERK, 1:2000, or anti-SAPK, 1:1000; Cell Signaling Technology) at $4^{\circ} \mathrm{C}$ overnight, then washed three times for $5 \mathrm{~min}$ and incubated for $1 \mathrm{~h}$ at room temperature in horseradish-peroxidase conjugated anti-rabbit IgG secondary antibodies (1:20,000; GE Healthcare) before being reacted with ECL + solution. The amount of activated MAPK was determined by normalizing the ratio of phosphorylated forms of MAPK to corresponding total MAPK on the same blot, and expressed in terms of percentage of variation to the control. Only changes of phosphorylated ERK2 (pERK2) were reported because the signal of pERK1 was often below detection threshold in our experimental conditions.

Histology. Mice were killed by decapitation, and whole brains were removed and slowly frozen in cooled isopentane $\left(-40^{\circ}\right)$. Coronal sections were cut in a cryostat (Leica, Rueil-Malmaison, France) maintained at approximately $-18^{\circ} \mathrm{C}$. Twenty micrometer brain sections were mounted on coated slides, and stained with $0.5 \%$ cresyl violet acetate. The sections were examined under a light macroscope (Leica Macroscope M420) and the location of injection needle tips was determined according to the standardized atlas plates of Paxinos and Watson (2001). Mice with injection needle placements outside of the boundaries of targeted areas were excluded from behavioral analysis. For the dorsal hippocampus, $\sim 15 \%$ of mice in each experiment showed cannula misplacement and were excluded from behavioral analysis. For somatosensory cortex, the percentage of excluded mice was $\sim 20 \%$ (data not shown).

Statistics. Data were analyzed by one-way or two-way ANOVA with the drug treatment as main factor or using unpaired Student's $t$ test for single-dose drug treatments (MK-801, SL327). When relevant, StudentNeuman-Keuls post hoc test was conducted for individual comparisons. One group Student's $t$ tests were used to compare discrimination index values to the chance level (50\%). For all comparisons the significance criterion was $p<0.05$.

\section{Results}

N/OFQ inhibits formation of long-term recognition memory We first studied the effects of intracerebroventricular infusions of N/OFQ peptide $(0.1,0.3$, and $1 \mathrm{nmol} ; n=6-7$ per dose $)$ on
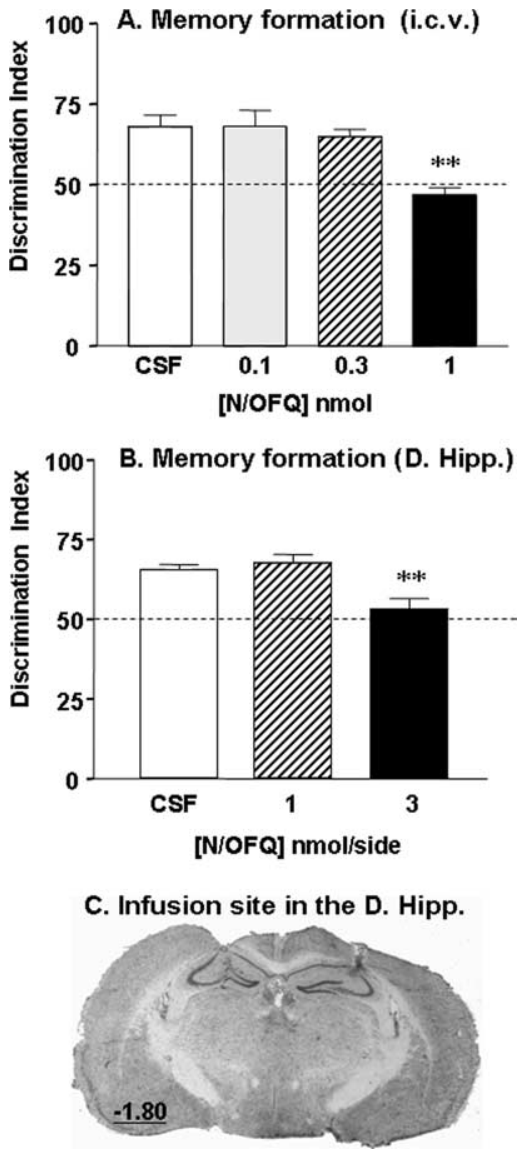

Figure 1. $\mathrm{N} / \mathrm{OFQ}$ peptide impairs long-term recognition memory formation. $A$, Deficits in object discrimination induced by intracerebroventricular injections of N/OFQ $(0.1,0.3$, and 1 $\mathrm{nmol} ; n=6-7$ per dose). $\boldsymbol{B}$, Deficits in object discrimination induced by bilateral N/OFQ infusions into the dorsal hippocampus (D. Hipp; 1 and $3 \mathrm{nmol} / \mathrm{side} ; n=7-9$ per dose). In both experiments, N/OFQ was administered before the familiarization trial and memory performance was assessed drug-free $24 \mathrm{~h}$ later during the choice trial. Data are presented as mean discrimination index \pm SEM. The dashed line materializes the chance level of $50 \%$ indicating equal exploration of both objects. C, Representative coronal section of the cannula placement in the dorsal hippocampus after cresyl violet acetate staining. The value indicates the distance in $\mathrm{mm}$ posterior to the bregma, according to the atlas of Paxinos and Watson (2001). ${ }^{* *} p<0.01$, significantly different from CSF-treated group.

long-term recognition memory. During the familiarization phase, CSF- and N/OFQ-treated mice displayed comparable exploration time of the object $\left[F_{(3,22)}=1.4\right.$, not significant (n.s.) $]$ (supplemental Table 1, available at www.jneurosci.org as supplemental material) and locomotor activity $\left(F_{(3,22)}=1.8\right.$, n.s.) (supplemental Table 1, available at www.jneurosci.org as supplemental material), indicating that the peptide did not affect locomotor function. In the subsequent choice trial, CSF-treated mice displayed good long-term memory performances as reflected by the DI significantly above the chance level $(p<0.05)$ (Fig. $1 A)$. In contrast, mice that received N/OFQ injections displayed reduced discrimination performances $\left(F_{(3,22)}=8.4 ; p<0.05\right)$ (Fig. $\left.1 A\right)$. Post hoc comparisons indicated that the $1 \mathrm{nmol}$ dose significantly impaired recognition memory compared with CSF treatment $(p<0.01)$ (Fig. 1A).

To identify the possible sites of action of N/OFQ, we examined the effects of bilateral infusions of the peptide into the dorsal hippocampus (Fig. 1C), a brain region that plays a key role in recognition memory and also highly expresses NOP receptors. Hippocampal infusions of N/OFQ ( 1 and $3 \mathrm{nmol} /$ 


\section{A. Object exploration}
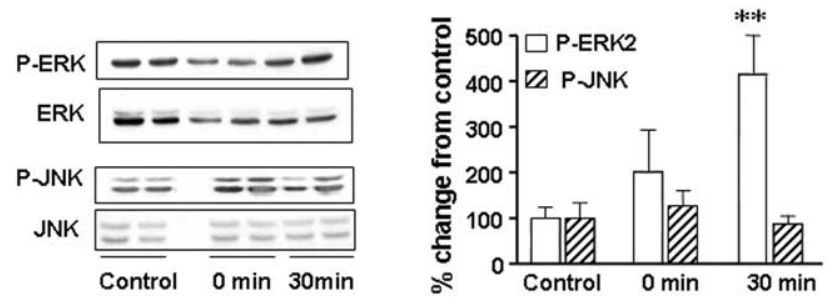

B. Erk activation
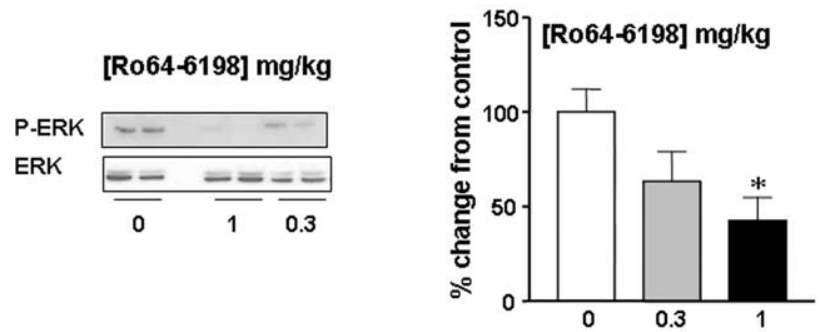

C. Memory formation
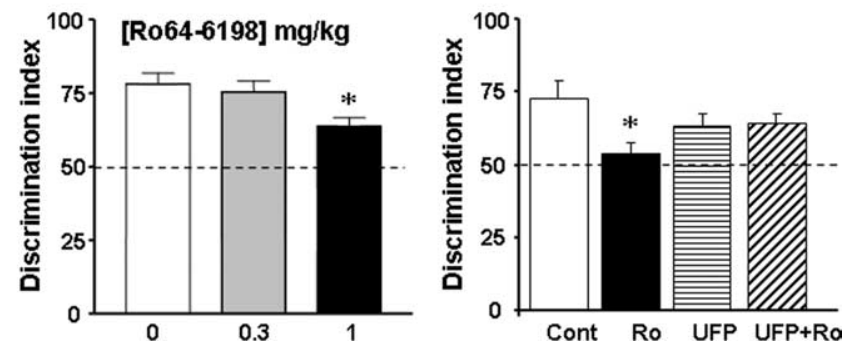

Figure 2. Activation of NOP receptors impairs long-term recognition memory formation through hippocampal ERK-dependent mechanisms. A, Hippocampal ERK and JNK phosphorylation after exploration of a novel object. Representative Western blots of phosphorylated and total forms of ERK and JNK in hippocampal samples collected either immediately $(n=4)$ or 30 $\min (n=4)$ after object exploration (duplicates). Histograms represent the mean percentage of change from control \pm SEM for $p E R K 2$ and $p J N K$ normalized to total ERK2 and JNK for each time point. Control group $(n=10)$ corresponds to samples collected immediately $(n=5)$ or $30 \mathrm{~min}$ $(n=5)$ after exposure of mice to an empty open field arena. Data from both control groups were pooled as MAPK levels were comparable. $\boldsymbol{B}$, Ro64-6198 reduces learning-induced hippocampal ERK activation. Western blots represent the phosphorylated and total forms of ERK2 (duplicates), $30 \mathrm{~min}$ after the familiarization trial. Histogram represents the mean percentage of change, from the vehicle-treated group \pm SEM, of normalized pERK2 immunoreactivity ( $n=4-6$ per dose). C, Left, Ro64-6198 (0,0.3, and $1 \mathrm{mg} / \mathrm{kg} ; n=9-10$ per dose) administered before the familiarization trial impairs long-term recognition memory formation. Right, Intrahippocampal infusion of the NOP receptor antagonist UFP-101 reverses Ro64-6198-induced memory deficits. Ro64-6198 (1 mg/kg) and UFP-101 (5 nmol/side) were administered separately or concurrently ( $n=7$ per treatment) before the familiarization trial. The dashed line materializes chance level of $50 \%$. ${ }^{*} p<0.05 ;{ }^{* *} p<0.01$, significantly different from vehicletreated group.

side, $n=7-9$ per dose) did not modify the time spent exploring the object $\left(F_{(2,21)}=0.1\right.$; n.s.) (supplemental Table 1, available at www.jneurosci.org as supplemental material) nor the total locomotor activity $\left(F_{(2,21)}=1.1\right.$; n.s.) (supplemental Table 1, available at www.jneurosci.org as supplemental material) during the familiarization trial. However, it markedly reduced object discrimination in the subsequent choice trial $\left(F_{(2,21)}=9.2 ; p<0.01\right)$ (Fig. $\left.1 B\right)$, and a significant memory impairment was obtained with $3 \mathrm{nmol}$ of N/OFQ $(p<0.01)$. Because of concerns that an injection volume of $0.25 \mu$ l to the dorsal hippocampus may have spread to adjacent areas, we studied the anatomical specificity of the amnesic effects of
N/OFQ ( $3 \mathrm{nmol}$ ) by infusing it above the hippocampus into the somatosensory cortex. Bilateral infusion of N/OFQ into this area, in the same conditions as hippocampal infusions, had no effect on object exploration during the familiarization trial $\left[T_{1} \mathrm{~A}(\mathrm{~s}), \mathrm{CSF}, n=6,7.5 \pm 1.2 ; \mathrm{N} / \mathrm{OFQ}, n=5,6.8 \pm 2.0\right.$, n.s.] and also failed to affect object discrimination performance during the choice trial (CSF, $66 \pm 1$; N/OFQ, $64 \pm 2$, n.s).

\section{NOP receptor activation inhibits recognition memory via hippocampal ERK signaling mechanisms}

To clarify the molecular mechanism of action of N/OFQ-NOP receptor system on hippocampal function, we first investigated the contribution of ERK and JNK signaling cascades in object recognition memory formation. The role of hippocampal ERK cascade in memory processes is now well established (Sweatt, 2001; Giovannini, 2006), but the role of JNK is still unclear. Western immunoblotting analysis revealed a time-dependent upregulation of ERK2 phosphorylation in the hippocampus of mice exposed to an object compared with those exposed to an empty open field arena $\left(F_{(2,15)}=7.0 ; p<0.01\right)$, and a robust ERK activation was detected at the 30 min time point $(p<0.01)$ (Fig. $2 A)$. However, no changes in hippocampal pJNK levels were detected immediately after or $30 \mathrm{~min}$ after familiarization with the $\operatorname{object}\left(F_{(2,12)}=0.5\right.$; n.s.) (Figure $\left.2 A\right)$, suggesting that this MAPK may not be recruited during the early phase of consolidation like ERK.

We then examined whether pharmacological inhibition of the ERK cascade affected recognition memory formation. Administration of SL327 $(50 \mathrm{mg} / \mathrm{kg})$, a specific inhibitor of the upstream kinase MEK, significantly reduced activated ERK2 level in the hippocampus (vehicle, $100 \pm 10$; SL327, $51 \pm 6$; $p<0.05 ; n=5$ per treatment). As expected, SL327 also lowered basal hippocampal pERK2 level under resting conditions (vehicle, $100 \pm 14$; SL327, $46 \pm 14 ; p<0.05 ; n=4$ per treatment), whereas it left pJNK levels intact (vehicle, $100 \pm 9$; SL327, $87 \pm 4$, n.s.; $n=4$ per treatment), thus confirming the pharmacological selectivity of this inhibitor. In the object recognition task, SL327 (50 mg/kg, $n=9$ ) did not affect locomotor activity nor object exploration during the familiarization trial (n.s. for both) (supplemental Table 2, available at www.jneurosci.org as supplemental material). In contrast, it significantly reduced discrimination performances in the subsequent choice trial (vehicle, $67 \pm 6$; SL327, $55 \pm 2 ; n=$ 8 and 9, respectively; $p<0.05$ ), confirming that ERK cascade activation is required for long-term recognition memory formation.

We next investigated whether NOP receptor activation could affect recognition memory formation through hippocampal ERK-dependent mechanisms. To this end, we used the selective and brain-penetrant NOP receptor agonist, Ro64-6198 (Jenck et al., 2000). Systemic administration of Ro64-6198 ( 0.3 and $1 \mathrm{mg} / \mathrm{kg}, n=6$ per dose), significantly reduced activated ERK2 level in the hippocampus $\left(F_{(2,21)}=\right.$ 4.6; $p<0.05)$, and a significant effect was detected at the 1 $\mathrm{mg} / \mathrm{kg}$ dose compared with the vehicle treatment $(p<0.05)$ (Fig. 2 B). In the object recognition task, Ro64-6198 (0.3 and 1 $\mathrm{mg} / \mathrm{kg}, n=9-10$ per dose) treatment had no effect on open field locomotor activity during the familiarization trial $\left(F_{(2,25)}\right.$ $=1.2$, n.s.) (supplemental Table 2, available at www. jneurosci.org as supplemental material), but significantly enhanced object exploration time at $1 \mathrm{mg} / \mathrm{kg}(p<0.01)$ (supplemental Table 2, available at www.jneurosci.org as supplemental material). During the choice trial, Ro64-6198-treated 
mice showed reduced object discrimination performances $\left(F_{(2,25)}=4.1 ; p<0.05\right)$ (Fig. $2 C$ ), and a significant effect was detected in the $1 \mathrm{mg} / \mathrm{kg}$ group $(p<0.05)$. To identify the possible site of action of Ro64-6198, we examined whether the blockade of hippocampal NOP receptors with the selective peptide antagonist UFP-101, could reverse Ro64-6198induced recognition memory impairment. Ro64-6198 treatment alone ( $1 \mathrm{mg} / \mathrm{kg}, n=7)$ had no effect on locomotor activity (n.s.) (supplemental Table 3, available at www. jneurosci.org as supplemental material), but enhanced object exploration during the familiarization trial. Accordingly, a significant main effect of Ro64-6198 treatment was detected on object exploration time $\left(F_{(1,22)}=5.26\right.$; $\left.p<0.05\right)$ (supplemental Table 3, available at www.jneurosci.org as supplemental material), but post hoc analysis failed to reach statistical significance. Intra-hippocampal infusions of UFP-101 alone ( $5 \mathrm{nmol} / \mathrm{side} ; n=7$ ) had no effect on locomotor activity nor object exploration time (n.s.) (supplemental Table 3, available at www.jneurosci.org as supplemental material). Also, no significant interaction was detected between drugs on both measures $\left(F_{(1,22)}=1.17\right.$, n.s.) (supplemental Table 3, available at www.jneurosci.org as supplemental material). In the choice trial, $1 \mathrm{mg} / \mathrm{kg}$ Ro64-6198 significantly impaired object discrimination $\left(F_{(1,22)}=4.35 ; p<0.05\right)$ (Fig. $\left.2 C\right)$. UFP-101 alone had no effect on discrimination performances $\left(F_{(1,22)}=0.01\right.$, n.s.), but reversed the memory impairment induced by Ro646198 (Ro64-6198 by UFP-101 interaction, $F_{(1,22)}=5.12 ; p<$ 0.05 ) (Fig. 2C).

Because Ro64-6198 enhanced object exploration, we verified that the memory deficits were not secondary to impaired perception and attention during the familiarization trial. To this end, we studied the effects of Ro64-6198 on recall after 24 h delay. When administered before the choice trial, Ro64-6198 (0.3 and $1 \mathrm{mg} /$ $\mathrm{kg} ; n=10-11$ per dose) had no effect on total locomotor activity $\left(F_{(2,28)}=0.2\right.$, n.s.) (supplemental Table 4, available at www. jneurosci.org as supplemental material), but the $1 \mathrm{mg} / \mathrm{kg}$ dose significantly enhanced object exploration $(p<0.05$ for both objects) (supplemental Table 4, available at www.jneurosci.org as supplemental material). Despite this increase in exploration, the overall recognition performances remained intact under Ro646198 treatment (vehicle, $71 \pm 2 ; 0.3 \mathrm{mg}, 77 \pm 4 ; 1 \mathrm{mg}, 70 \pm 5$; $F_{(2,28)}=0.9$, n.s.) indicating that the drug did not affect information retrieval processes nor object perception. In a final set of experiments, we assessed the effects of Ro64-6198 on memory using a short retention delay ( $3 \mathrm{~h}$ ). Again, no effects of Ro64-6198 were detected on short-term recognition memory $\left(F_{(2,23)}=0.6\right.$, n.s.; $n=8-9$ per dose) (supplemental Fig. $1 A$, available at www.jneurosci.org as supplemental material) or recall performances $\left(F_{(2,33)}=1.1\right.$, n.s.; $n=12$ per dose) (supplemental Fig. $1 B$, available at www.jneurosci.org as supplemental material). These results show that the NOP receptor agonist preferentially impaired mnemonic processes related to long-term consolidation through an action on hippocampal NOP receptors. They also suggest that amnesic effects may be linked to the inhibition of hippocampal ERK activation which is required for long-term recognition memory formation.

NOP and NMDA receptors regulate recognition memory formation via common ERK signaling mechanisms

Electrophysiological studies indicate that N/OFQ inhibits synaptic transmission and plasticity in the hippocampus through suppression of glutamatergic function at the NMDA receptor (Manabe et al., 1998; Yu and Xie, 1998; Wei and Xie, 1999;
Bongsebandhu-phubhakdi and Manabe, 2007). Based on these findings, we hypothesized that NOP receptors may regulate recognition memory by interacting with NMDA receptor signaling in the hippocampus. As expected, the blockade of NMDA receptors with systemic administration of the noncompetitive antagonist, MK-801 $(0.1 \mathrm{mg} / \mathrm{kg})$, significantly reduced learning-induced ERK2 activation in the hippocampus (vehicle, $100 \pm 9$; MK-801, $29 \pm 7 ; p<0.01 ; n=6$ per treatment). MK-801 also impaired discrimination performances in the choice trial (vehicle, $71 \pm 3$; MK-801, $55 \pm 6$; $p<0.05 ; n=11$ and 12 per treatment), confirming the requirement of the NMDA receptor in long-term recognition memory formation. Because MK-801 enhanced locomotor activity (vehicle, $3339 \pm 234$; MK-801, $4513 \pm 288 ; p<0.05$ ) and object exploration (vehicle, $6.6 \pm 0.8$; MK-801, $20.2 \pm$ $4.0 ; p<0.05)$ during the familiarization trial, we tested whether the amnesic effects of this psychotomimetic could relate to impaired perception and attention. We studied the effects of MK- 801 ( 0 and $0.1 \mathrm{mg} / \mathrm{kg}, n=7$ and 8 per treatment) on recall, as we did with Ro64-6198. MK-801 produced a marked locomotor hyperactivity during the choice trial $(p<$ 0.01 ) (supplemental Table 4, available at www.jneurosci.org as supplemental material), but had no effect on object exploration times (n.s. for both objects) (supplemental Table 4, available at www.jneurosci.org as supplemental material). Despite the hyperlocomotion, MK-801-treated mice accurately discriminated the familiar object from the novel one (vehicle, $65 \pm 6$; MK-801, $64 \pm 4$, n.s.), indicating that the NMDA receptor antagonist did not interfere with information retrieval processes.

In search of a functional interaction between NOP and NMDA receptors, we studied the effects of coadministration of silent doses of Ro64-6198 (0.3 mg/kg) and MK-801 (0.01 mg/kg) on activated hippocampal ERK ( $n=4-6$ per treatment) (Fig. $3 A$ ) and memory performances $(n=7-8$ per treatment) (Fig. $3 B$ ). Overall ANOVA revealed a significant main effect of treatment on activated ERK2 level in the hippocampus $\left(F_{(3,21)}=9.7\right.$; $p<0.05)$, and post hoc analysis indicated that only the combination significantly suppressed ERK2 activation ( $p<0.01$, Fig. $3 A)$. In the object recognition task, all drug treatments enhanced locomotor activity and exploration time during the familiarization trial $\left(F_{(3,25)}=11.2 ; p<0.05\right)$ (supplemental Table 5, available at www.jneurosci.org as supplemental material). In the subsequent choice trial, only the combination significantly impaired longterm recognition memory $(p<0.01)$ (Fig. $3 B)$, in such a manner that mice were unable to discriminate between the novel and the familiar object (DI not different from chance level, n.s). Together, these results indicate that hippocampal MAPK/ERK is one of the biochemical pathways mediating NOP and NMDA receptors influence on long-term recognition memory formation.

\section{NOP and NMDA receptors differentially regulate} spontaneous hippocampal ERK and JNK activities

In this series of experiments, we examined whether Ro64-6198 and MK-801 could affect basal pERK and pJNK levels in the hippocampus. Western immunoblotting analyses were performed on hippocampi of mice that received Ro64-6198 (0.3, 1, and $3 \mathrm{mg} / \mathrm{kg}, n=4$ per dose) or MK-801 ( 0.1 and $0.3 \mathrm{mg} / \mathrm{kg}, n=$ $4-5$ per dose) in their home cage. None of the pharmacological treatments affected total ERK or JNK levels in the hippocampus (data not shown). Similarly, none of the Ro64-6198 doses tested changed baseline pERK2 or pJNK levels $\left(F_{(3,12)}=0.1\right.$, n.s., and 

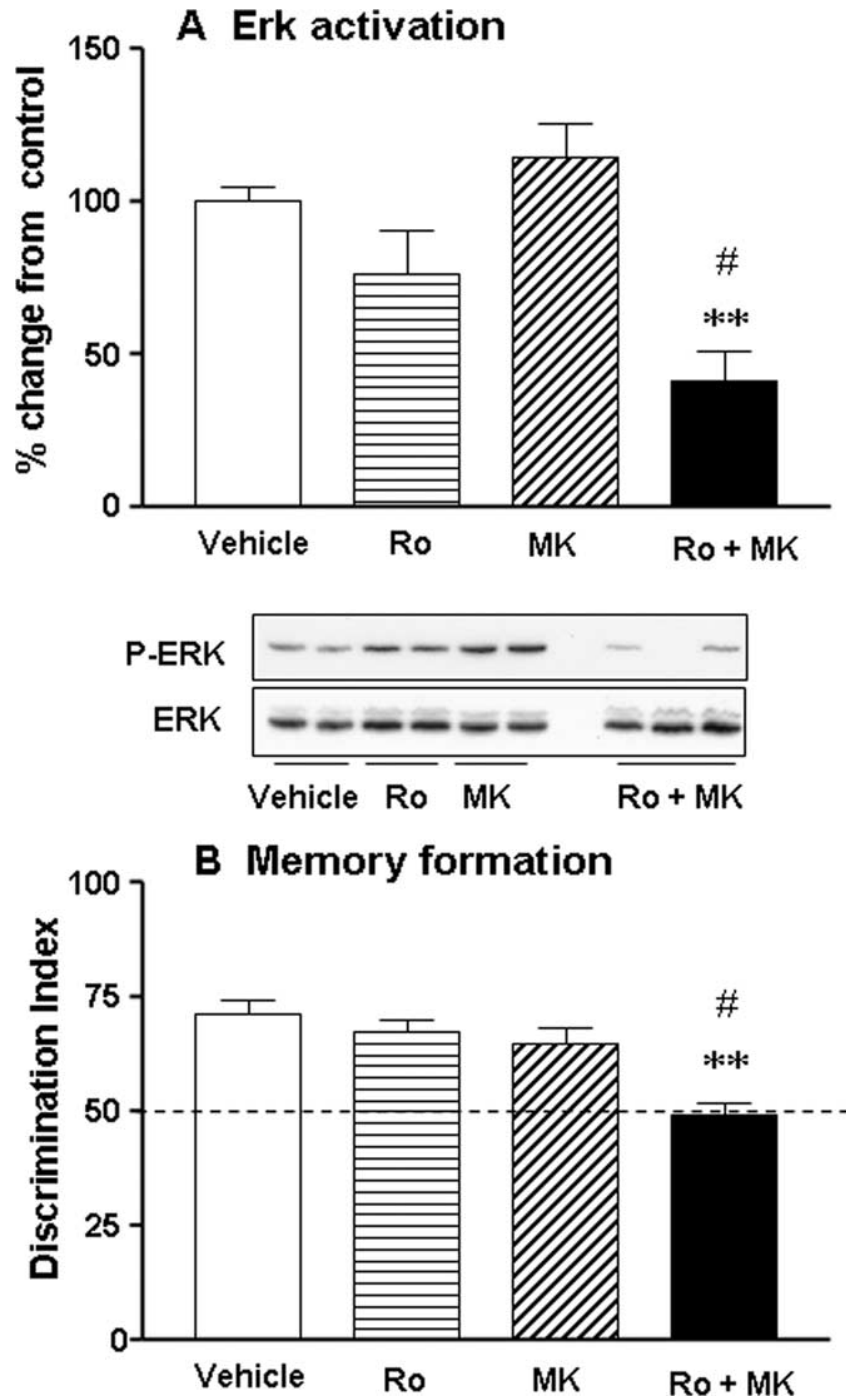

Figure 3. NOP and NMDA receptors modulate recognition memory formation through common hippocampal ERK-dependent mechanisms. $\boldsymbol{A}$, Western blots represent the phosphorylated and total forms of ERK2 $30 \mathrm{~min}$ after the familiarization trial. Ro64-6198 $(0.3 \mathrm{mg} / \mathrm{kg})$ and MK-801 $(0.01 \mathrm{mg} / \mathrm{kg})$ were administered separately or concurrently before the familiarization trial ( $n=2-3$ mice per treatment represented). Histograms represent the mean percentage of change from the vehicle-treated group \pm SEM for normalized $p E R K 2$ immunoreactivity for each pharmacological treatment ( $n=4-6$ per treatment). B, Coadministration of Ro64-6198 (0.3 $\mathrm{mg} / \mathrm{kg})$ and MK-801 $(0.01 \mathrm{mg} / \mathrm{kg})$ synergistically impairs long-term recognition memory $(n=$ 7-8 per treatment). Data are represented as the mean discrimination index \pm SEM. The dashed line shows a chance level of $50 \% .{ }^{* *} p<0.01$, significantly different from vehicletreated group and "significantly different from all other groups.

$F_{(3,12)}=0.9$, n.s., respectively) (Table 1). It should be pointed out that the highest dose $(3 \mathrm{mg} / \mathrm{kg})$ impaired home cage activity as it produced a clear sedation (Higgins et al., 2001; Reiss et al., 2008). However, NMDA receptor blockade with MK-801 resulted in strong dephosphorylation of pERK2 $\left(F_{(2,10)}=4.5 ; p<0.05\right)$ as well as pJNK in the hippocampus $\left(F_{(2,10)}=30.5 ; p<0.05\right)$, and significant effects were detected with $0.3 \mathrm{mg} / \mathrm{kg}$ dose for both MAPKs ( $p<0.05$ for both) (Table 1$)$.

Finally, we found no evidence for a synergistic interaction between Ro64-6198 (1 mg/kg) and MK-801 (0.1 mg/kg) under resting conditions (n.s.) (Table 1), suggesting that the facilitatory effects of NMDA receptor on spontaneous hippocampal ERK and JNK activities may be independent of NOP receptor modulation. Together, these results show that NOP and NMDA recep-
Table 1. Effects of Ro64-6198 and MK-801 administered alone or concurrently on basal PERK and P-JNK levels in the hippocampus

\begin{tabular}{lcc}
\hline Treatment & $\begin{array}{l}\text { P-ERK } \\
\text { (\% control) }\end{array}$ & $\begin{array}{l}\text { P-JNK } \\
\text { (\% control) }\end{array}$ \\
\hline $\begin{array}{l}\text { Ro64-6198 (mg/kg, i.p.) } \\
\quad \text { Vehicle }(n=4)\end{array}$ & \\
$0.3(n=4)$ & $100 \pm 30$ & $100 \pm 15$ \\
$1(n=4)$ & $101 \pm 18$ & $73 \pm 14$ \\
$\quad 3(n=4)$ & $110 \pm 12$ & $75 \pm 17$ \\
MK-801 (mg/kg, s.c.) & $93 \pm 22$ & $87 \pm 8$ \\
$\quad$ Vehicle $(n=4)$ & $100 \pm 21$ & $100 \pm 15$ \\
$0.1(n=5)$ & $89 \pm 27$ & $102 \pm 12$ \\
$0.3(n=4)$ & $36 \pm 8^{*}$ & $38 \pm 5^{*}$ \\
Ro64-6198 + MK-801 & & \\
Vehicle $(n=4)$ & $100 \pm 19$ & $100 \pm 4$ \\
$1+0.1 \mathrm{mg}(n=4)$ & $71 \pm 36$ & $77 \pm 18$ \\
\hline
\end{tabular}

Mice were given Ro64 -6198 or MK-801 injections separately or concurrently in the home cage, and changes in basal P-ERK and P-JNK levels were assessed 30 min later. Data are expressed as mean \pm SEM. ${ }^{*} p<0.05$ versus vehicle-treated group.

tors differentially contribute to the modulation of basal ERK and JNK signaling in the hippocampus.

\section{Discussion}

The present study shows that N/OFQ-NOP receptor system negatively modulates formation of long-term recognition memory through ERK-dependent signaling mechanisms in the hippocampus. This modulation is in part mediated by antagonism of glutamatergic function at the NMDA receptor. The lack of effect of NOP receptor activation on basal pERK level further suggests that N/OFQ modulatory role is activitydependent as recently demonstrated by electrophysiological approaches (Manabe et al., 1998; Bongsebandhu-phubhakdi and Manabe, 2007).

Previous studies have demonstrated the role of N/OFQ-NOP receptor system in working memory, spatial and fear learning (Hiramatsu and Inoue, 1999; Redrobe et al., 2000; Higgins et al., 2002; Mamiya et al., 2003; Sandin et al., 2004; Roozendaal et al., 2007), but the contribution of this novel neuropeptide system in modulation of recognition memory have not been investigated. Here, we show that intracerebroventricular infusion of N/OFQ or systemic administration of the selective NOP receptor agonist, Ro64-6198, impairs long-term object recognition memory formation in mice. Ro64-6198 also enhanced object investigation, an effect that seems to reflect a genuine stimulant action of this agonist as it was observed after the exposure of mice to a novel as well as to a familiar object (supplemental Table 5, available at www.jneurosci.org as supplemental material). Furthermore, low doses $(<0.1 \mathrm{nmol})$ of N/OFQ itself were reported to enhance exploratory behavior in mice (Florin et al., 1996; Kamei et al., 2004). Most importantly, at doses increasing exploration, Ro64-6198 treatment had no effects on acquisition or short-term memory, and also failed to affect recall performances regardless of the retention delay ( 3 or $24 \mathrm{~h}$ ). These findings strongly suggest that the NOP receptor agonist selectively interferes with mnemonic processes related to long-term consolidation processes. This is in line with previous studies showing that N/OFQ abolishes long-term retention of fear conditioning and passive avoidance when administered post-training (Mamiya et al., 2003; Roozendaal et al., 2007). Interestingly, when injected into the dorsal hippocampus, N/OFQ severely impaired long-term recognition memory formation, without any apparent effects on sensorimotor functions. Furthermore, the amnesic effects of Ro64-6198 were reversed by coadministration of the selective NOP receptor antagonist, UFP-101, thus confirming that they are 
mediated by hippocampal NOP receptors. Together, these results extend previous studies showing that N/OFQ negatively modulates spatial learning in the hippocampus (Sandin et al., 1997; Sandin et al., 2004). They also suggest that the dorsal hippocampus is the critical brain structure mediating the amnesic effects we observed after systemic or intracerebroventricular administrations of the NOP receptor agonists.

Hippocampal ERK/MAPK plays a central role in different types of memories, including contextual fear conditioning, inhibitory passive avoidance and spatial memory (Sweatt, 2004; Davis and Laroche, 2006; Giovannini, 2006). However, its involvement in recognition memory formation is still unclear. Whereas Kelly et al. (2003) showed an upregulation of ERK phosphorylation in the hippocampus of rats tested in the object recognition task, these results were not observed in mice (Kamei et al., 2006; Nagai et al., 2007). One possible reason for this discrepancy could be the differences in the time-points used for quantifications of pERK changes in the hippocampus. Indeed, as reported by Nagai et al. (2007) (see also Kamei et al., 2006), we found no changes in hippocampal pERK levels immediately after exposure to a novel object. In contrast, a robust activation was observed 30 min later, a time-point that approximately corresponds to the study by Kelly et al. (2003). Furthermore, pharmacological inhibition of ERK pathway after systemic administration of SL327 (Nagai et al., 2007; present study) or intrahippocampal infusions of PD98059 (Nagai et al., 2007) prevented long-term recognition memory formation in mice, thus confirming the necessity of this signaling pathway in consolidation processes.

Upstream activation of ERK pathway may occur via many neurotransmitter receptors that facilitate memory formation. The NMDA subtype of glutamate receptor was previously shown to be an upstream component of hippocampal ERK activation in fear conditioning (Atkins et al., 1998). Here, we demonstrate that this is also the case in the object recognition task, as illustrated by the disruptive effects of the noncompetitive antagonist MK-801 on ERK activation and long-term memory. The amnesic effects of MK- 801 cannot be attributed to altered baseline synaptic transmission, because no changes in spontaneous ERK and JNK activities were detected under resting conditions at the $0.1 \mathrm{mg} / \mathrm{kg}$ dose. Furthermore, MK801 failed to affect recall performances, which also rules out a nonspecific action on perception. These findings are in broad agreement with those reported in the literature showing that systemic or intrahippocampal NMDA receptor blockade impairs long-term consolidation of object recognition memory (Baker and Kim, 2002; de Lima et al., 2005). The NMDA receptor can activate ERK via multiple $\mathrm{Ca}^{2+}$-dependent signaling transduction pathways, including the Ras/Raf/MEK and cAMP-dependent cascades (Poser and Storm, 2001; Sweatt, 2004). After activation, ERK processes several events relevant for establishing long-term memory. In particular, ERK translocates to the nucleus to initiate the transcriptional activity necessary for synaptic plasticity and long-term consolidation processes (Poser and Storm, 2001; Sweatt, 2004).

Previous in vitro studies reported stimulatory actions of N/OFQ on ERK signaling pathways in cell lines transfected with NOP receptor (Fukuda et al., 1997; New and Wong, 2002). Here, we show that in living animals NOP receptor activation inhibits ERK pathway in the hippocampus. Most importantly, we found a clear association between the suppressive effects of Ro64-6198 on ERK activation and recognition memory formation. The lack of effects of Ro64-6198 on basal pERK level indicates that NOP receptors may primarily modulate changes mediated by other neurotransmitter systems, which are triggered during learning. The similarity of the profile of action of Ro64-6198 and MK-801 at behavioral and molecular levels strongly point toward a functional antagonism between N/OFQ and glutamatergic systems. Furthermore, combined treatments with subthreshold doses produced a synergistic inhibition of memory performances and ERK activation. These results are complementary to those reported in NOP receptor knock-out mice showing that antagonism of N/OFQ transmission improves fear memory through NMDA receptor-dependent mechanisms (Mamiya et al., 2003). They also provide the first evidence that NOP and NMDA receptors converge on common ERK pathway in the hippocampus to regulate memory formation. However, it cannot be excluded that the amnesic effects of Ro64-6198 might also involve a cholinergic component (Cavallini et al., 2003; Uezu et al., 2005) that is known to contribute to recognition memory formation (Dodart et al., 1997; Bertaina-Anglade et al., 2006) and to activate ERK cascade in neurons (Rosenblum et al., 2000; Giovannini, 2006; Steiner et al., 2007)

Functional interaction between NOP and NMDA receptors may involve both presynaptic and postsynaptic mechanisms. For instance, this could occur at the level of neuronal circuitry, as N/OFQ was shown to suppress synaptic transmission in many brain regions, including the hippocampus, through presynaptic inhibition of neurotransmitters release (Meis, 2003). NOP receptors are also located on interneurons and pyramidal cells throughout the hippocampus (Houtani et al., 2000), and can therefore directly modulate NMDA receptor function at the postsynaptic level. Consistent with this view, electrophysiological studies showed that exogenous as well as endogenous N/OFQ potently inhibits NMDA receptor-dependent long-term potentiation through direct action on pyramidal and granule cells in the hippocampus (Yu and Xie, 1998; Bongsebandhu-phubhakdi and Manabe, 2007). NOP receptor is a G-protein-coupled receptor that negatively regulates the activity of adenylate cyclases, inhibits voltage-gated $\mathrm{Ca}^{2+}$ channels and activates inward rectifying $\mathrm{K}^{+}$channels. By blocking $\mathrm{Ca}^{2+}$ current and inhibiting cAMP production (New and Wong, 2002), NOP receptor can suppress the activation of multiple cascades that ultimately converge on ERK, and thereby disrupts NMDA receptor-mediated recognition memory formation. In this regard, Mamiya et al. (2003) have shown that NOP and NMDA receptors modulate in an opposing manner the activity of $\mathrm{Ca}^{2+} /$ calmodulin-dependent protein kinase II (CaMKII) in hippocampal slice. CaMKII was proposed to act as a trigger of Ras/Raf/MEK cascade (Micheau and Riedel, 1999; Blitzer et al., 2005), and may thus be one potential upstream target that could relay the influences of NOP and NMDA receptors on ERK activity at postsynaptic level. Our failure to detect an effect of Ro64-6198 and MK-801 cotreatments on spontaneous ERK activity indicates that the cross talk between NOP and NMDA receptors may particularly take place in behaviorally relevant situations, such as those involving learning. The lack of effect of the high doses of Ro64-6198 (3 mg/kg) on spontaneous ERK activity further suggest that NOP receptors do not modulate this signaling cascade under resting conditions, unlike NMDA receptors. All together, the above findings show that NOP receptor negatively modulates ERK signaling cascade in the hippocampus. This inhibitory action is particularly potent in learning conditions, when the tonic activity of other neurotransmitters that promote ERK phosphorylation, such as glutamate, is enhanced. 


\section{References}

Atkins CM, Selcher JC, Petraitis JJ, Trzaskos JM, Sweatt JD (1998) The MAPK cascade is required for mammalian associative learning. Nat Neurosci 1:602-609.

Baker KB, Kim JJ (2002) Effects of stress and hippocampal NMDA receptor antagonism on recognition memory in rats. Learn Mem 9:58-65.

Bertaina-Anglade V, Enjuanes E, Morillon D, Drieu la Rochelle C (2006) The object recognition task in rats and mice: a simple and rapid model in safety pharmacology to detect amnesic properties of a new chemical entity. J Pharmacol Toxicol Methods 54:99-105.

Blitzer RD, Iyengar R, Landau EM (2005) Postsynaptic signaling networks: cellular cogwheels underlying long-term plasticity. Biol Psychiatry 57:113-119.

Bongsebandhu-phubhakdi S, Manabe T (2007) The neuropeptide nociceptin is a synaptically released endogenous inhibitor of hippocampal longterm potentiation. J Neurosci 27:4850-4858.

Cavallini S, Marino S, Beani L, Bianchi C, Siniscalchi A (2003) Nociceptin inhibition of acetylcholine efflux from different brain areas. NeuroReport 14:2167-2170.

Chiou LC, Liao YY, Fan PC, Kuo PH, Wang CH, Riemer C, Prinssen EP (2007) Nociceptin/orphanin FQ peptide receptors: pharmacology and clinical implications. Curr Drug Targets 8:117-135.

Darland T, Grandy DK (1998) The orphanin FQ system: an emerging target for the management of pain? Br J Anaesth 81:29-37.

Daumas S, Halley H, Frances B, Lassalle JM (2005) Encoding, consolidation, and retrieval of contextual memory: differential involvement of dorsal CA3 and CA1 hippocampal subregions. Learn Mem 12:375-382.

Davis S, Laroche S (2006) Mitogen-activated protein kinase/extracellular regulated kinase signalling and memory stabilization: a review. Genes Brain Behav 5 [Suppl 2]:61-72.

de Lima MN, Laranja DC, Bromberg E, Roesler R, Schroder N (2005) Pre- or post-training administration of the NMDA receptor blocker MK-801 impairs object recognition memory in rats. Behav Brain Res 156:139-143

Dodart JC, Mathis C, Ungerer A (1997) Scopolamine-induced deficits in a two-trial object recognition task in mice. NeuroReport 8:1173-1178.

Fischer A, Radulovic M, Schrick C, Sananbenesi F, GodovacZimmermann J, Radulovic J (2007) Hippocampal Mek/Erk signaling mediates extinction of contextual freezing behavior. Neurobiol Learn Mem 87:149-158

Florin S, Suaudeau C, Meunier JC, Costentin J (1996) Nociceptin stimulates locomotion and exploratory behaviour in mice. Eur J Pharmacol 317:9-13.

Fukuda K, Shoda T, Morikawa H, Kato S, Mori K (1997) Activation of mitogen-activated protein kinase by the nociceptin receptor expressed in Chinese hamster ovary cells. FEBS Lett 412:290-294.

Giovannini MG (2006) The role of the extracellular signal-regulated kinase pathway in memory encoding. Rev Neurosci 17:619-634.

Higgins GA, Grottick AJ, Ballard TM, Richards JG, Messer J, Takeshima H, Pauly-Evers M, Jenck F, Adam G, Wichmann J (2001) Influence of the selective ORL1 receptor agonist, Ro64-6198, on rodent neurological function. Neuropharmacology 41:97-107.

Higgins GA, Kew JN, Richards JG, Takeshima H, Jenck F, Adam G, Wichmann J, Kemp JA, Grottick AJ (2002) A combined pharmacological and genetic approach to investigate the role of orphanin FQ in learning and memory. Eur J Neurosci 15:911-922.

Hiramatsu M, Inoue K (1999) Nociceptin/orphanin FQ and nocistatin on learning and memory impairment induced by scopolamine in mice. Br J Pharmacol 127:655-660.

Houtani T, Nishi M, Takeshima H, Sato K, Sakuma S, Kakimoto S, Ueyama T, Noda T, Sugimoto T (2000) Distribution of nociceptin/orphanin FQ precursor protein and receptor in brain and spinal cord: a study using in situ hybridization and X-gal histochemistry in receptor-deficient mice. J Comp Neurol 424:489-508.

Jenck F, Wichmann J, Dautzenberg FM, Moreau JL, Ouagazzal AM, Martin JR, Lundstrom K, Cesura AM, Poli SM, Roever S, Kolczewski S, Adam G, Kilpatrick $\mathrm{G}$ (2000) A synthetic agonist at the orphanin FQ/nociceptin receptor ORL1: anxiolytic profile in the rat. Proc Natl Acad Sci USA 97:4938-4943.

Kamei J, Matsunawa Y, Miyata S, Tanaka S, Saitoh A (2004) Effects of nociceptin on the exploratory behavior of mice in the hole-board test. Eur J Pharmacol 489:77-87.

Kamei H, Nagai T, Nakano H, Togan Y, Takayanagi M, Takahashi K, Koba- yashi K, Yoshida S, Maeda K, Takuma K, Nabeshima T, Yamada K (2006) Repeated methamphetamine treatment impairs recognition memory through a failure of novelty-induced ERK1/2 activation in the prefrontal cortex of mice. Biol Psychiatry 59:75-84.

Kelly A, Laroche S, Davis S (2003) Activation of mitogen-activated protein kinase/extracellular signal-regulated kinase in hippocampal circuitry is required for consolidation and reconsolidation of recognition memory. J Neurosci 23:5354-5360.

Liu EH, Lee TL, Nishiuchi Y, Kimura T, Tachibana S (2007) Nocistatin and its derivatives antagonize the impairment of short-term acquisition induced by nociceptin. Neurosci Lett 416:155-159.

Mamiya T, Yamada K, Miyamoto Y, Konig N, Watanabe Y, Noda Y, Nabeshima T (2003) Neuronal mechanism of nociceptin-induced modulation of learning and memory: involvement of $N$-methyl-D-aspartate receptors. Mol Psychiatry 8:752-765.

Manabe T, Noda Y, Mamiya T, Katagiri H, Houtani T, Nishi M, Noda T, Takahashi T, Sugimoto T, Nabeshima T, Takeshima H (1998) Facilitation of long-term potentiation and memory in mice lacking nociceptin receptors. Nature 394:577-581.

Meis S (2003) Nociceptin/orphanin FQ: actions within the brain. Neuroscientist 9:158-168.

Meis S, Pape HC (1998) Postsynaptic mechanisms underlying responsiveness of amygdaloid neurons to nociceptin/orphanin FQ. J Neurosci 18:8133-8144.

Meunier JC, Mollereau C, Toll L, Suaudeau C, Moisand C, Alvinerie P, Butour JL, Guillemot JC, Ferrara P, Monsarrat B, et al (1995) Isolation and structure of the endogenous agonist of opioid receptor-like ORL1 receptor. Nature 377:532-535.

Micheau J, Riedel G (1999) Protein kinases: which one is the memory molecule? Cell Mol Life Sci 55:534-548.

Nagai T, Takuma K, Kamei H, Ito Y, Nakamichi N, Ibi D, Nakanishi Y, Murai M, Mizoguchi H, Nabeshima T, Yamada K (2007) Dopamine D1 receptors regulate protein synthesis-dependent long-term recognition memory via extracellular signal-regulated kinase $1 / 2$ in the prefrontal cortex. Learn Mem 14:117-125.

Neal Jr CR, Mansour A, Reinscheid R, Nothacker HP, Civelli O, Watson Jr SJ (1999a) Localization of orphanin FQ (nociceptin) peptide and messenger RNA in the central nervous system of the rat. J Comp Neurol 406:503-547.

Neal Jr CR, Mansour A, Reinscheid R, Nothacker HP, Civelli O, Akil H, Watson Jr SJ (1999b) Opioid receptor-like (ORL1) receptor distribution in the rat central nervous system: comparison of ORL1 receptor mRNA expression with (125)I-[(14)Tyr]orphanin FQ binding. J Comp Neurol 412:563-605.

New DC, Wong YH (2002) The ORL1 receptor: molecular pharmacology and signalling mechanisms. Neurosignals 11:197-212.

Paxinos G, Franklin KBJ (2001) The mouse brain in stereotaxic coordinates, Ed 2. San Diego: Academic.

Poser S, Storm DR (2001) Role of $\mathrm{Ca}^{2+}$-stimulated adenylyl cyclases in LTP and memory formation. Int J Dev Neurosci 19:387-394.

Redrobe JP, Calo G, Guerrini R, Regoli D, Quirion R (2000) [Nphe(1)]Nociceptin (1-13) NH(2), a nociceptin receptor antagonist, reverses nociceptin-induced spatial memory impairments in the Morris water maze task in rats. Br J Pharmacol 131:1379-1384.

Reinscheid RK, Nothacker HP, Bourson A, Ardati A, Henningsen RA, Bunzow JR, Grandy DK, Langen H, Monsma Jr FJ, Civelli O (1995) Orphanin FQ: a neuropeptide that activates an opioidlike $\mathrm{G}$ protein-coupled receptor. Science 270:792-794.

Reiss D, Wichmann J, Tekeshima H, Kieffer BL, Ouagazzal AM (2008) Effects of nociceptin/orphanin FQ receptor (NOP) agonist, Ro64-6198, on reactivity to acute pain in mice: Comparison to morphine. Eur J Pharmacol 579:141-148.

Roozendaal B, Lengvilas R, McGaugh JL, Civelli O, Reinscheid RK (2007) Orphanin FQ/nociceptin interacts with the basolateral amygdala noradrenergic system in memory consolidation. Learn Mem 14:29-35.

Rosenblum K, Futter M, Jones M, Hulme EC, Bliss TV (2000) ERKI/II regulation by the muscarinic acetylcholine receptors in neurons. J Neurosci 20:977-985.

Sandin J, Georgieva J, Schott PA, Ogren SO, Terenius L (1997) Nociceptin/ orphanin FQ microinjected into hippocampus impairs spatial learning in rats. Eur J Neurosci 9:194-197.

Sandin J, Ogren SO, Terenius L (2004) Nociceptin/orphanin FQ modulates 
spatial learning via ORL-1 receptors in the dorsal hippocampus of the rat. Brain Res 997:222-233.

Selcher JC, Atkins CM, Trzaskos JM, Paylor R, Sweatt JD (1999) A necessity for MAP kinase activation in mammalian spatial learning. Learn Mem $6: 478-490$.

Steiner RC, Heath CJ, Picciotto MR (2007) Nicotine-induced phosphorylation of ERK in mouse primary cortical neurons: evidence for involvement of glutamatergic signaling and CaMKII. J Neurochem 103:666-678.

Sweatt JD (2001) The neuronal MAP kinase cascade: a biochemical signal integration system subserving synaptic plasticity and memory. J Neurochem 76:1-10.

Sweatt JD (2004) Mitogen-activated protein kinases in synaptic plasticity and memory. Curr Opin Neurobiol 14:311-317.
Uezu K, Sano A, Sei H, Toida K, Houtani T, Sugimoto T, Suzuki-Yamamoto T, Takeshima H, Ishimura K, Morita Y (2005) Enhanced hippocampal acetylcholine release in nociceptin-receptor knock-out mice. Brain Res 1050:118-123.

Wei WZ, Xie CW (1999) Orphanin FQ suppresses NMDA receptordependent long-term depression and depotentiation in hippocampal dentate gyrus. Learn Mem 6:467-477.

Yu TP, Xie CW (1998) Orphanin FQ/nociceptin inhibits synaptic transmission and long-term potentiation in rat dentate gyrus through postsynaptic mechanisms. J Neurophysiol 80:1277-1284.

Yu TP, Fein J, Phan T, Evans CJ, Xie CW (1997) Orphanin FQ inhibits synaptic transmission and long-term potentiation in rat hippocampus. Hippocampus 7:88-94. 